\title{
Sodium-Glucose Cotransporter-2 Inhibitors Improve Cardiovascular Dysfunction in Type 2 Diabetic East Asians
}

\author{
Muhammad Afzal ${ }^{1}{ }^{(}$, , Fahad A. Al-Abbasi ${ }^{2}$, Muhammad Shahid Nadeem ${ }^{2}\left(\mathbb{D}\right.$, Sultan Alshehri ${ }^{3}{ }^{(D}$, \\ Mohammed M. Ghoneim ${ }^{4}{ }^{-}$, Syed Sarim Imam ${ }^{3}{ }^{(\mathbb{C}}$, Waleed Hassan Almalki ${ }^{5}$ and Imran Kazmi ${ }^{2, *(\mathbb{C}}$ \\ 1 Department of Pharmacology, College of Pharmacy, Jouf University, Sakaka 72341, Saudi Arabia; \\ afzalgufran@ju.edu.sa \\ 2 Department of Biochemistry, Faculty of Science, King Abdulaziz University, Jeddah 21589, Saudi Arabia; \\ fabbasi@kau.edu.sa (F.A.A.-A.); mhalim@kau.edu.sa (M.S.N.) \\ 3 Department of Pharmaceutics, College of Pharmacy, King Saud University, Riyadh 11451, Saudi Arabia; \\ salshehri1@ksu.edu.sa (S.A.); simam@ksu.edu.sa (S.S.I.) \\ 4 Department of Pharmacy Practice, College of Pharmacy, AlMaarefa University, \\ Ad Diriyah 13713, Saudi Arabia; mghoneim@mcst.edu.sa \\ 5 Department of Pharmacology, College of Pharmacy, Umm Al-Qura University, Makkah 21955, Saudi Arabia; \\ Whmalki@uqu.edu.sa \\ * Correspondence: ikazmi@kau.edu.sa
}

\section{check for} updates

Citation: Afzal, M.; Al-Abbasi, F.A.; Nadeem, M.S.; Alshehri, S.; Ghoneim, M.M.; Imam, S.S.; Almalki, W.H.; Kazmi, I. Sodium-Glucose

Cotransporter-2 Inhibitors Improve Cardiovascular Dysfunction in Type 2 Diabetic East Asians. Metabolites 2021, 11,794. https://doi.org/10.3390/ metabo11110794

Academic Editors: Gloria Formoso and Maria P.A. Baldassarre

Received: 29 September 2021

Accepted: 17 November 2021

Published: 21 November 2021

Publisher's Note: MDPI stays neutral with regard to jurisdictional claims in published maps and institutional affiliations.

Copyright: (c) 2021 by the authors. Licensee MDPI, Basel, Switzerland. This article is an open access article distributed under the terms and conditions of the Creative Commons Attribution (CC BY) license (https:// creativecommons.org/licenses/by/ $4.0 /)$.
Abstract: In East Asians, the incidence of type 2 DM (T2DM) has increased as a result of major alterations in life. Cardiovascular problems are more likely in those with T2DM. Sodium-glucose cotransporter-2 (SGLT2) inhibitors are novel insulin-independent antihyperglycemic drugs that limit renal glucose reabsorption and thereby improve glycemic control. They are used alone or in combination with insulin and other antihyperglycemic medications to treat diabetes, and they are also helpful in protecting against the progression of complications. This review has evaluated the available evidence not only on the efficacy of SGLT2 inhibitors in T2DM, but also on their favourable cardiovascular events in East Asians. DM is an independent risk factor for cardiovascular diseases. As a result, in addition to glycemic control in diabetes management, the therapeutic goal in East Asian diabetic patients should be to improve adverse cardiovascular outcomes. Besides establishing antidiabetic effects, several studies have reported cardioprotective benefits of SGLT2 inhibitors via numerous pathways. SGLT2 inhibitors show promising antidiabetic drugs with potential cardiovascular advantages, given that a high number of diabetic patients in East Asia have co-existing cardiovascular disorders. Despite significant positive results in favour of SGLT2, more research is needed to determine how SGLT2 inhibitors exert these impressive cardiovascular effects.

Keywords: cardioprotection; East Asians; diabetes mellitus; SGLT2 inhibitors; insulin independent

\section{Introduction}

Diabetes mellitus (DM) is a complex metabolic disorder with a serious global impact on community health concerns in the 21st century [1]. Diabetes is becoming more common worldwide, with Asia leading the way [2]. The rise in the occurrence of type 2 DM (T2DM) can be attributed to ageing, rapid urbanization, and some environmental and genetic factors in Asia [3]. Undiagnosed diabetes and poor glucose tolerance are also significant contributors to Asia's high prevalence of diabetes [4]. Several distinguishing elements of the Asian region can be used to extrapolate the causes of this significant rise in diabetes incidence. The prevalence and long-term management of diabetic complications have increased alarmingly, imposing a massive economic hardship on countries and healthcare systems. Diabetes consumes approximately $5 \%$ to $20 \%$ of total health spending in many countries, posing a barrier to long-term economic growth [5]. 


\section{Feature Affects the High Occurrence of Diabetes in East Asians}

The International Diabetes Federation (IDF) has reported the national and international incidence of diabetes since 2000. In the IDF Diabetes Atlas, 9th edition, an estimated approximately 436 million individuals are affected worldwide, with a considerable proportion being East Asians. By 2030, the global load is predicted to reach 578 million people, rising to seven hundred million by 2045 [1]. Furthermore, according to the most recent IDF Diabetes Atlas 2019, 9th edition, approximately 116.4 million Chinese people have diabetes, making China the country with the highest number of cases in the world [1]. Figure 1 depicts a comparison of East Asian countries' diabetes statistics (Diabetes Atlas, 2019). The factors affecting the high frequency of diabetes in Asian people with a typical ethnic background include lifestyle changes, metabolic syndrome, and an increase in the occurrence of obesity and T2DM. In many East Asian countries, urbanization, industrialization, and internal rural-to-urban migration are rapidly occurring, resulting in a number of negative consequences, including decreased exercise, a shift in diet to high calorie and significant increases in BMI (body mass index) and adiposity in the upper body [6-8]. Additionally, as a result of socioeconomic advancement, the proportion of people suffering from diseases caused by daily life modifications, i.e., DM, obesity, and cardiac disease, has increased. In terms of genetic and ecological risk factors for DM and cardiovascular disease, Asian populations have several important characteristics. Growing scientific data suggests that no one therapy prescription can be made for the entire world's population.

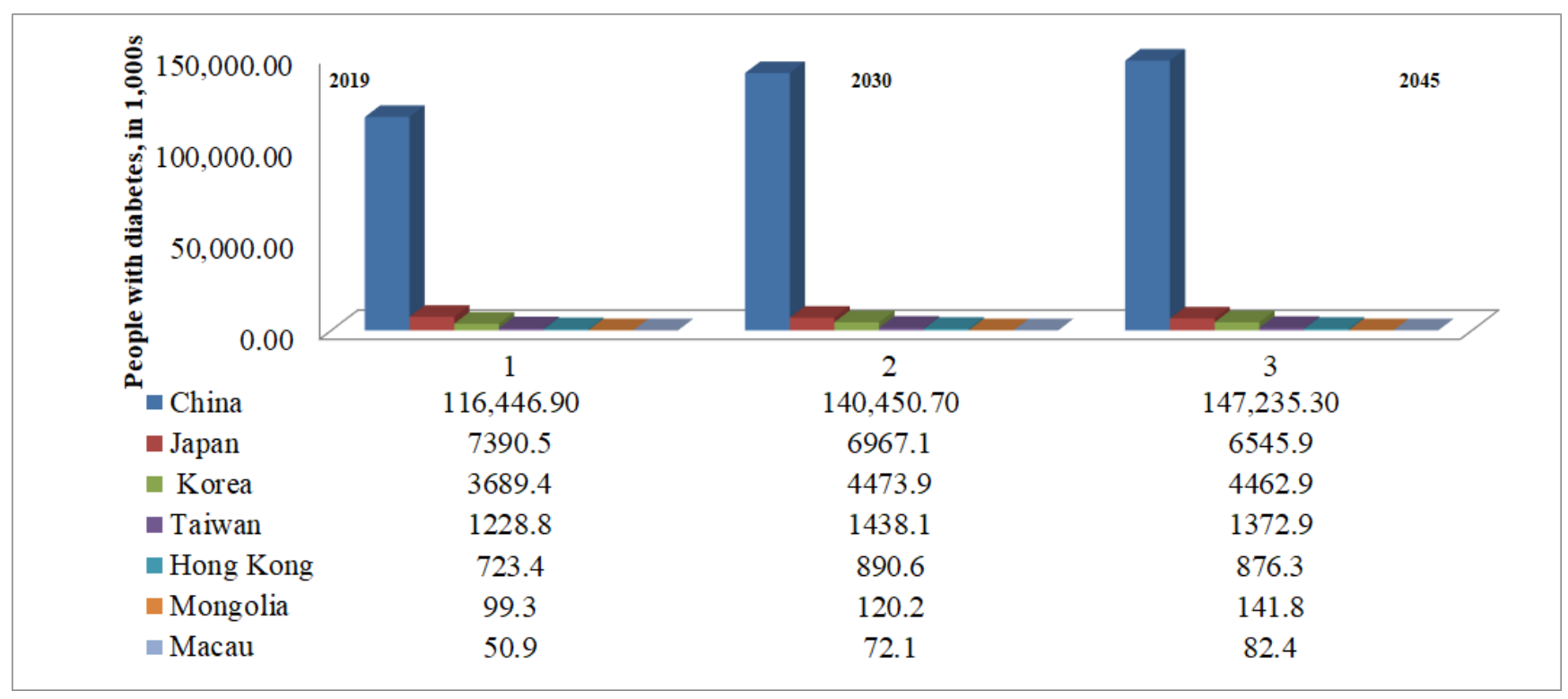

Figure 1. Comparison of information about diabetes between East Asian countries.

\section{Genetic Factors}

Type 2 diabetes is caused by complex interactions between multiple genetic susceptibility factors, as well as environmental and behavioural factors. Several diabetes genes have recently been revealed in Asians according to genome-wide association studies $[9,10]$. Several type 2 diabetes mellitus (T2DM) susceptibility loci have been identified in or near GLIS3, PEPD, FITM2-R3HDML-HNF4A, KCNK16, MAEA, GCC1-PAX4, PSMD6, and ZFAND [11]. The majority of these polymorphisms are thought to have an impact on T2DM risk by altering insulin secretion. GLIS3 has been linked to fasting glucose levels and has been linked to pancreatic beta cell development and insulin gene expression. TCF7L2 regulates the gene expression of relevant receptors, which modulates beta-cell responses to GLP-1 and GIP. Aside from nuclear DNA variants, mitochondrial DNA (mtDNA) polymorphisms/mutations, such as the mtDNA A3243G mutation and the mtDNA T16189C polymorphism, are also essential in determining diabetes risk [12]. 


\section{Risk Factors Associated with Incidence of T2DM and Complications}

Several risk factors lead to the incidence of diabetes and complications, including BMI (body mass index), extra visceral fat, diabetes onset at an early age, significant historical changes over the last decade, cardiovascular disease (CVD), insufficient $\beta$-cell response to counter insulin resistance, high alcohol intake, sedentary lifestyle, obesity or being overweight, high rate of childhood obesity, gestational diabetes, and increased inflammatory markers [13].

The previous review of Asian diabetes epidemiology established that untreated diabetes and impaired blood glucose tolerance reflect the rising incidence of DM in various East Asian countries [2]. Furthermore, the rise in gestational diabetes mellitus brings with it additional issues, such as DM's risk in females and longstanding repercussions on the newborn or progeny. The high frequency and risk factors of gestational DM have been found in a systematic review study, which may be attributable to the grow in mother age and obesity [14]. One of the most striking observations in East Asians is the prevalence of T2DM at a body mass index [15]. According to the large cohort, having an elevated BMI was related to an augmented risk of DM due to insulin resistance and deteriorating $\beta$-cell function [16]. Higher fatty acid inflow into the liver, altered adipokine synthesis, hepatic steatosis, and hepatic glucose resistance are all possible consequences of increased visceral adiposity [17]. Ectopic fat accumulation in non-adipocyte tissue leads to cellular dysfunction and death, including inflammation and finally apoptosis. As a result, lipotoxicity in $\beta$-cell may thus reduce and dysfunctional secretion cause T2DM [4]. As highlighted earlier, increased insulin resistance due to visceral adiposity tissue can disrupt the balance, resulting in minimised insulin-production ability in East Asians [18]. Because of genetic abnormalities affecting $\beta$-cell mass and insulin production, East Asians have an increased chance of acquiring diabetes. Multiple unique T2DM loci have been discovered in East Asian investigations, with many of these variations projected to alter T2DM risk via influencing insulin secretion [19]. They could play a role in Asians' lower insulin production activity. The exact mechanisms underlying these and their subsequent associations remain unclear. Both thirty-five-genotype and -phenotype hypotheses appear to have a role in the spread of DM among Asians, which is marked by an early age of onset, a proclivity for $\beta$-cell malfunction, and abdominal obesity [20]. T2DM is a predisposition to expand diabetes at an early age in the East Asian population. Due to genetic susceptibility, early development of T2DM has elevated the risk of micro- and macrovascular issues, a greater proclivity for $\beta$-cell dysfunction, and long-term disease duration [21]. The rising popularity of weight gain, particularly among young males, is a major contributor to the onset of T2DM. Even though not all obese people get DM, it is obvious that they are at a higher risk. Elevated levels of inflammatory indicators have been linked to the onset and development of cardiac events and T2DM [22]. The association between elevated markers of inflammation and constant cardio-metabolic diseases has been studied in epidemiology and clinical investigations [23]. Among some proinflammatory cytokines discovered within interleukin 1 (IL-1), islets cells seem to play an important role in the initiation and propagation of $\beta$-cell inflammation and dysfunction [24]. Lascar et al. proposed a possible association between young-onset T2DM and an increased pro-inflammatory pathway [25]. In addition, young-onset T2DM faces some challenges in diabetes management, such as the complexity of drug treatment, acceptance of insulin therapy, adherence to blood glucose monitoring, social stigma, and job stress. As a result, antihyperglycemic medications lower blood glucose levels, have a longer glycemic effect, and are easier to administer [26].

\section{SGLT2 Inhibitors in T2DM Cure in Asians}

East Asians have also increased the continued burden of diabetes [27]. Insulinindependent SGLT2 (sodium-glucose cotransporter) inhibitors are a type of antidiabetic drug. Sodium-glucose cotransporters (SGLT) are two distinct types of active cotransporters (types 1 and 2) that are primarily found in the brush border of the S2 and S3 segments of the proximal renal tubules as well as in the intestines. By inhibiting SGLT2, these drugs 
prevent glucose and salt from being reabsorbed in the proximal renal tubule, resulting in increased sodium and glucose excretion in the urine. Inhibitors of SGLT2 provide an antihyperglycemic action that is independent of insulin but reliant on renal function and plasma insulin level, the impact becoming less active when glucose falls below the normal physiological range [28]. The American Diabetes Association and the European Diabetes Association both recommend SGLT2 inhibitors as first- or second-line DM treatment [29]. The most common side effect of SGLT2 inhibitors appears to be genito-urinary genital infections, which have been shown to rise up to fourfold in clinical trials. Insulin-independent secretion mechanisms enable SGLT2 inhibitors to be used alone or in combination with insulin and other antihyperglycemic drugs. Additionally, it is expected to be useful in East Asian T2DM patients, especially considering the reduced insulin secretory capacity in Asians. SGLT2 inhibitors have been shown to improve insulin susceptibility and $\beta$-cells and enhance cardiac and renal outcomes in people with T2DM, according to recent research [29-31]. The SGLT2 inhibitor was found to lower systolic and diastolic pressure in both elevated-pressure cases and non-hypertensive DM [32]. By inhibiting SGLT2, a minimum affinity and high capacity transporter, glucose reabsorption in the proximal tubule is mediated [33]. Previous research suggested that SGLT2 and overexpression of glucose transport 2 enhanced renal glucose reabsorption in T2DM patients [4]. Evidence was proposed that SGLT2 inhibitors lowered the renal glucose excretion threshold. Furthermore, SGLT2 inhibitor-induced glycosuria enhances insulin and $\beta$-cell function, resulting in lower blood glucose levels [34]. Succeeding studies in global genetic knockout mice showed that SGLT2 inhibitors were linked to decreased plasma insulin level, higher insulin susceptibility, and improved $\beta$-cell activity, all of which supported this concept [35]. SGLT2 inhibitors increased glucagon release from $\alpha$-cells in the pancreatic islet, which increased endogenous glucose synthesis. In addition to their effects on glucose homeostasis, SGLT2 inhibitors have been found to lower CVD risk [36]. SGLT2 inhibitors consist of different mechanisms of glucose control effect with reduced insulin resistance and sustained long-term glycemic control; insulin-independent action ensures longer control, systolic blood pressure, BMI, albuminuria, visceral fat, uric acid, plasma volume, arterial stiffness, inflammation, oxidative stress, sympathetic nervous system, and major adverse cardiac events [33,37-40]. In the United States and European Union, the Food and Drug Administration has permitted dapagliflozin, canagliflozin, and empagliflozin (SGLT2 selective inhibitors) [41-43]. Key studies of SGLT2 inhibitors, with either mono or dual therapy, in East Asians with T2DM are listed in Table 1. When compared to other second-line medications and others, SGLT2 inhibitors have proved to have greater blood glucose-lowering effects. In East Asians, the prevalence of low insulin caused by SGLT2 inhibitors were moderately lower and well tolerated [44]. In East Asia, multiple innovative scientific studies have shown the efficacy of SGLT2 inhibitors in lowering sugar levels. SGLT2 inhibitors were shown to lower $\mathrm{HbA1c}$ and insulin dosage in diabetes mellitus patients without a significant risk of hypoglycemia by Yang et al., suggesting that insulin resistance is improving [45]. In individuals with T2DM, clinical studies using the most advanced SGLT2 inhibitors, dapagliflozin and canagliflozin, have shown therapeutic improvements in terms of glycemic control, plasma glucose level, and reduced weight gain. $\mathrm{HbA1c}$ and bodyweight reductions have shown an additive effect of combining SGLT2 inhibitors with metformin [46]. According to studies, add-on SGLT2 inhibitors provided a better glucose-lowering impact than switch treatment [47,48]. A previous study in Taiwan reported a similar finding: those who switched from a DPP-4 inhibitor to an SGLT2 inhibitor experienced significant improvements, whereas those who remained on a DPP-4 inhibitor did not $[49,50]$. In Japanese patients, luseogliflozin combined with liraglutide improves glycemic control and leads to weight loss [51]. SGLT2 inhibitors are drugs that prevent the enzyme SGLT2 from functioning properly. Tofogliflozin may help patients recover from impaired $\beta$-cell activity if their insulin secretion capacity is preserved to some extent, according to a study of patients with elevated insulin stages at start-up [52]. In East 
Asian patients with T2DM, empagliflozin was found to be a well-tolerated and safe choice in placebo-controlled trials by pooled analysis [53].

Table 1. SGLT2 inhibitors studies on both mono and double therapy in East Asians.

\begin{tabular}{|c|c|c|c|}
\hline Author; Region & $\begin{array}{l}\text { Study Design and } \\
\text { Population }\end{array}$ & $\begin{array}{c}\text { Drug } \\
\text { Therapy }\end{array}$ & Key Findings \\
\hline $\begin{array}{l}\text { Yang et al. } \\
\text { China [54] }\end{array}$ & $\begin{array}{l}\text { 24-week, } \\
\text { randomized, Phase 3, } \\
\text { double-blind, } \\
\text { placebo-controlled } \\
\quad(n=272)\end{array}$ & Dapagliflozin & $\begin{array}{c}\text { Significant reduction with Dapagliflozin } \\
\text { HbA1c } \\
\text { Fasting plasma glucose } \\
\text { Body weight }\end{array}$ \\
\hline $\begin{array}{l}\text { Kawamori et al. } \\
\text { Japanese [55] }\end{array}$ & $\begin{array}{l}\text { 52-week, } \\
\text { randomized, } \\
\text { double-blind, } \\
\text { placebocontrolled study } \\
(n=433)\end{array}$ & Empagliflozin & $\begin{array}{c}\text { Significant reduction with Empagliflozin } \\
\text { HbA1c } \\
\text { Fasting plasma glucose } \\
\text { Body weight } \\
\text { Systolic blood pressure }\end{array}$ \\
\hline $\begin{array}{l}\text { Kutoh et al. } \\
\text { Japanese [56] }\end{array}$ & $\begin{array}{l}\text { 3-month, } \\
\text { observational } \\
\quad(n=36)\end{array}$ & Canagliflozin & $\begin{array}{l}\text { Significant reduction with Canagliflozin } \\
\text { HbA1c } \\
\text { Free fatty acid } \\
\text { Body weight } \\
\text { insulin resistance }\end{array}$ \\
\hline $\begin{array}{l}\text { Osonoi et al. } \\
\text { Japanese [57] }\end{array}$ & $\begin{array}{l}\text { 12-week, } \\
\text { open label study } \\
\quad(n=20)\end{array}$ & Canagliflozin & $\begin{array}{c}\text { Significant reduction with Canagliflozin } \\
\text { HbA1c } \\
\text { Fasting plasma glucose } \\
\text { Body weight }\end{array}$ \\
\hline $\begin{array}{l}\text { Furukawa et al. } \\
\text { Japanese [58] }\end{array}$ & $\begin{array}{l}\text { 24-week, } \\
\text { open label study } \\
\quad(n=104)\end{array}$ & Dapagliflozin & $\begin{array}{c}\text { Significant reduction with Dapagliflozin } \\
\text { HbA1c } \\
\text { Fasting plasma glucose } \\
\text { Body weight } \\
\text { low-density lipoprotein cholesterol }\end{array}$ \\
\hline $\begin{array}{l}\text { Han et al. } \\
\text { Korean [59] }\end{array}$ & $\begin{array}{l}\text { 24-week, } \\
\text { randomized, } \\
\text { placebo-controlled, } \\
\text { double-blind study } \\
\quad(n=104)\end{array}$ & Ipragliflozin & $\begin{array}{c}\text { Sustained reduction with Ipragliflozin } \\
\text { HbA1c } \\
\text { Fasting plasma glucose } \\
\text { Body weight } \\
\text { Fasting serum insulin }\end{array}$ \\
\hline $\begin{array}{l}\text { Chieh-Hsiang Lu et al. } \\
\text { Korea and Taiwan [60] }\end{array}$ & $\begin{array}{l}\text { 24-week, } \\
\text { multicenter, } \\
\text { placebo-controlled, } \\
\text { double-blind, } \\
\text { parallel-group } \\
(n=87)\end{array}$ & Ipragliflozin & $\begin{array}{l}\text { Significant reduction with Ipragliflozin } \\
\text { HbA1 } \\
\text { Fasting plasma glucose } \\
\text { Body weight and waist circumference } \\
\text { low-density lipoprotein cholesterol }\end{array}$ \\
\hline
\end{tabular}

\section{Cardiovascular Axis of SGLT2 Inhibitors}

In contrast to many other anti-diabetic agents, SGLT2 inhibition represents a promising approach to treating diabetes (Figure 2). SGLT2 inhibitors have been explored in a number of cardiac trials in patients with T2DM, with SGLT2 inhibitors lowering cardiac events [61-63]. In type 2 diabetic patients with a high CV risk or a history of severe CVD or advanced renal illness, SGLT2 inhibitors significantly prevent major adverse cardiovascular events, CV death, heart failure, and renal outcomes [64,65]. In individuals with T2DM, SGLT2 inhibitors improve cardiac performance indirectly by increasing natriuresis and diuresis, which decrease interstitial and plasma fluid quantities, dropping cardiac preload [66]. A decrease in stable cardiac rate was also linked to improvements in adipose tissue insulin resistance [67]. Enhanced cardiac fitness and the combination of SGLT2 inhibitors and loop diuretics was explored in people with T2DM and congestive heart failure $[68,69]$. Furthermore, SGLT2 inhibitors have been shown to create a condition 
of "fasting mimicry", which stimulates the adenosine monophosphate-activated protein kinase and enzymes sirtuin 1, whose favourable anti-inflammatory actions may aid in heart function improvement [70]. SGLT2 inhibitors lower arterial blood pressure without increasing heart rate significantly, suggesting a link with a decrease in the sympathetic nervous system [71]. SGLT2 inhibitors show favourable effects on the sympathetic nervous systems function's circadian rhythm, which may contribute to SGLT2 inhibitors' clinical ability to improve blood pressure profiles and might produce good cardiac outcomes [72]. It has also been proposed that SGLT2 inhibitors can induce vasodilation by triggering the voltage-gated potassium channels and protein kinase G [73]. The direct vascular effects of SGLT2 inhibition, in addition to the natriuresis effects of SGLT2 inhibition, may play a role in the favourable hemodynamic effects described with SGLT2 inhibition. SGLT2 inhibitors natriuretic effect may contribute to cardiorenal benefits by inhibiting the myocardial sodium-proton exchanger, which has been shown to reduce cardiac hypertrophy and heart failure [74]. SGLT2 inhibitors raise glucagon levels, which have inotropic and chronotropic effects on the heart [75]. SGLT2 inhibitors have the potential to alter electrophysiology in the heart. A previous study found that using SGLT2 inhibitors decreases arterial stiffness and improves endothelial dysfunction [76]. Moreover, attenuation in endothelial dysfunction and arterial stiffness by reducing oxidative stress has also been reported, bringing potential benefits in vascular diseases. Diabetes, both type 1 and type 2 DM, empagliflozin improves arterial stiffness and vascular resistance [77]. Furthermore, glucosuria caused by SGLT-2 inhibition causes a series of metabolic changes that are likely to decrease fibrosis, inflammation and plaque formation, all of which have potential cardiac effects [78]. According to a previous study, dapagliflozin can reduce myocardial fibrosis and cardiac remodelling through modulating macrophage morphologies [79]. Inhibition of SGLT2 protects the cardiac against ischemia/reperfusion damage [80]. This beneficial effect is linked to a decline in calmodulin kinase II activity, which leads to increased $\mathrm{Ca}^{2+}$ flux and contractility in the sarcoplasmic reticulum. SGLT2 inhibition reduces epicardial fat mass and levels of bioactive molecules such as tumour necrosis factor-a and plasminogen activator inhibitor-1 in diabetic patients with CVD [81]. This may help to reduce the adverse remodelling of the failing heart. Empagliflozin considerably lowers cardiac interstitial fibrosis, pericoronary arterial fibrosis, arterial thickness, cardiac interstitial macrophage infiltration, and cardiac superoxide levels, according to Lin et al. [82]. Higher cardiac ketone oxidation mediated by empagliflozin gives an extra source of fuel for the heart in diabetic cardiomyopathic mice, which is allied with enhanced cardiac activity [83].

Dapagliflozin reduces heart failure hospitalisation and cardiac events in DM patients, according to a large-scale randomised controlled trial and real-world studies [84-86]. When compared to a placebo, SGLT2 inhibitors can significantly avoid gaining body weight [87]. These conclusions have significant clinical inferences for Asians, as higher abdominal obesity contributes to insulin resistance, which leads to a risk of CVD. Dapagliflozin may demonstrate a dual function in improving glycemic control and lowering the risk of CVD in the Asian population. The practise of SGLT 2 inhibitors appears to be related to decreased levels of atherogenic, small, intense, low-density cholesterol in open-label Japanese cohorts [88]. In Chinese individuals with T2DM, the occurrence of chronic renal disorder and reduced hematocrit levels elevated the risk of severe cardiac outcomes. Elevated hematocrit levels in diabetic patients after SGLT2 inhibitor treatment may reverse kidney remodelling. During therapy with empagliflozin, elevated hematocrit levels were linked to a lower risk of cardiovascular death $[89,90]$. These findings imply that SGLT2 inhibitors may have the potential to decrease the cardiac burden in DM (Figure 3). 


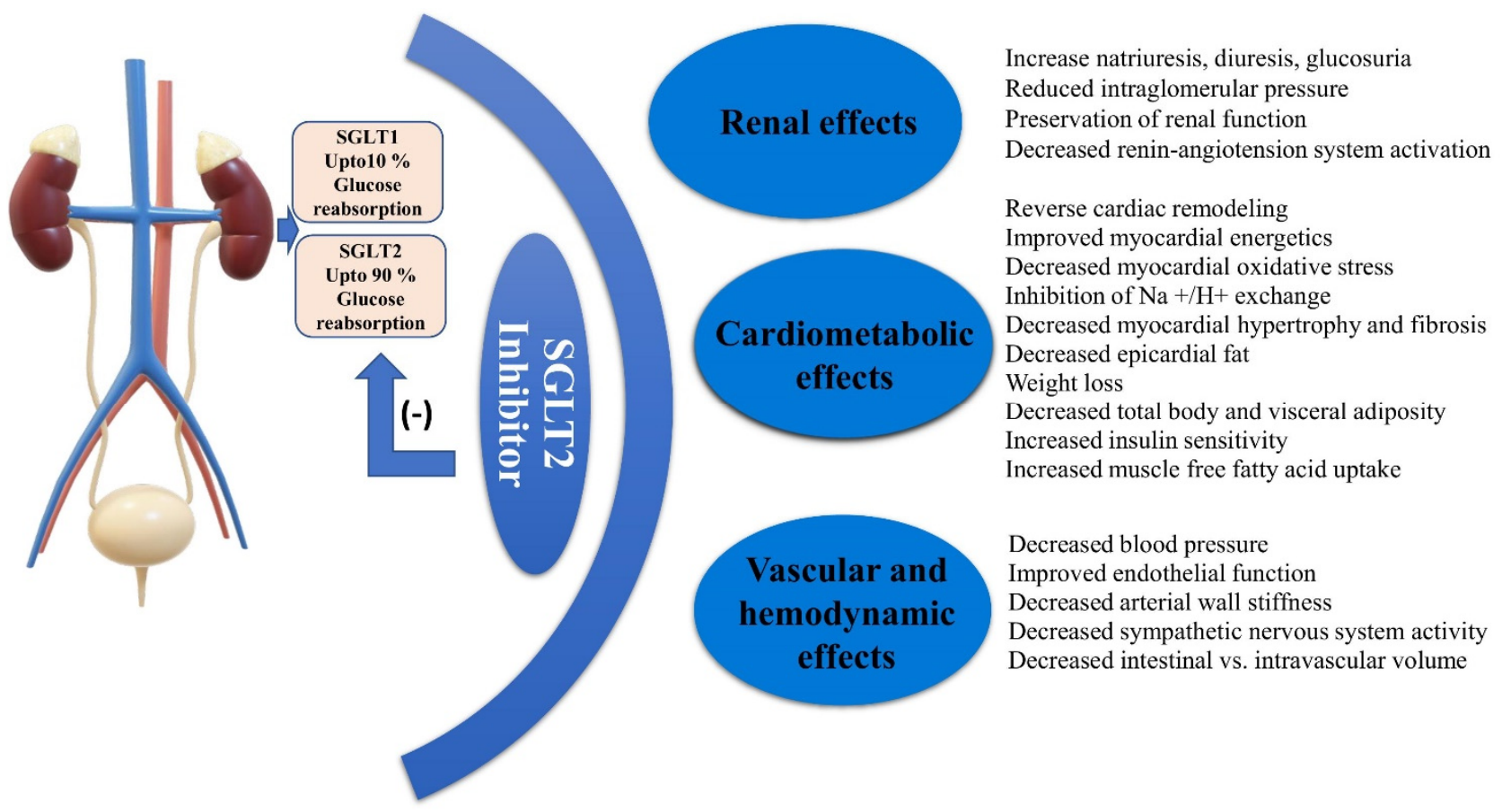

Figure 2. The proposed cardiovascular axis of SGLT2 inhibitor via several pleiotropic mechanisms.

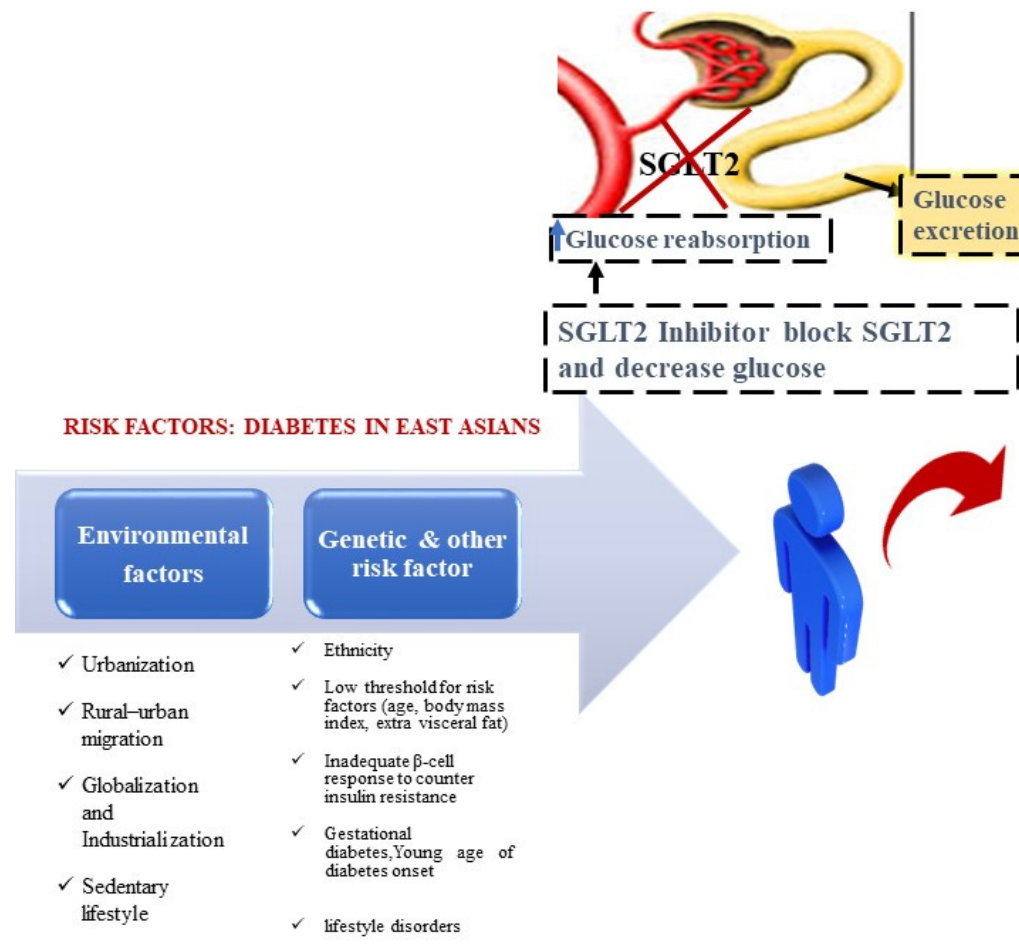

Figure 3. Effects of SGLT2 inhibitors on Type 2 diabetes mellitus and cardiovascular system.

\section{Conclusions}

East Asians are at higher risk due to an increased prevalence of diabetes. The following factors contribute to the improved incidence of T2DM and the ethnic-specific character of East Asians, insulin secretion, rising BMI, stress, a proclivity for visceral fat, decreased pancreatic $\beta$-cell mass, diabetes onset at an early age, and cardiac events. SGLT2 inhibitors are novel antihyperglycemic agents with the possibility to progress in glycemic manage- 
ment while posing an incredibly low risk of hypoglycemia, insulin independence, and cardioprotection.

Author Contributions: M.A. wrote the manuscript; I.K. and F.A.A.-A. supervised; M.S.N., S.A., M.M.G. and S.S.I. revised manuscript; and W.H.A. provided resources. All authors have read and agreed to the published version of the manuscript.

Funding: This work was funded by Deanship of Scientific Research at Jouf University, Saudi Arabia (grant number DSR-2021-01-0321).

Acknowledgments: The authors are thankful to the Deanship of Scientific Research at Jouf University, Saudi Arabia for funding this research under the grant number DSR-2021-01-0321.

Conflicts of Interest: The authors have no conflict of interest.

\section{References}

1. Saeedi, P.; Petersohn, I.; Salpea, P.; Malanda, B.; Karuranga, S.; Unwin, N.; Colagiuri, S.; Guariguata, L.; Motalae, A.A.; Ogurtsova, K. Global and regional diabetes prevalence estimates for 2019 and projections for 2030 and 2045: Results from the International Diabetes Federation Diabetes Atlas. Diabetes Res. Clin. Pract. 2019, 157, 107843. [CrossRef]

2. Priyadi, A.; Muhtadi, A.; Suwantika, A.A.; Sumiwi, S.A. An economic evaluation of diabetes mellitus management in South East Asia. J. Adv. Pharm. Edu. Res. 2019, 9, 53-74.

3. Hu, F.B. Globalization of diabetes: The role of diet, lifestyle, and genes. Diabetes Care 2011, 34, 1249-1257. [CrossRef]

4. Nanditha, A.; Ma, R.C.; Ramachandran, A.; Snehalatha, C.; Chan, J.C.; Chia, K.S.; Zimmet, P.Z. Diabetes in Asia and the Pacific: Implications for the global epidemic. Diabetes Care 2016, 39, 472-485. [CrossRef]

5. Lim, L.L.; Tan, A.; Moses, K.; Rajadhyaksha, V.; Chan, S.P. Place of sodium-glucose cotransporter-2 inhibitors in East Asian subjects with type 2 diabetes mellitus: Insights into the management of Asian phenotype. J. Diabetes Its Complicat. 2016, 31, 494-503. [CrossRef] [PubMed]

6. Yoon, K.H.; Lee, J.H.; Kim, J.W.; Cho, J.H.; Choi, Y.H.; Ko, S.H.; Zimmet, P.; Son, H.Y. Epidemic obesity and type 2 diabetes in Asia. Lancet 2006, 368, 1681-1688. [CrossRef]

7. Chan, J.C.; Malik, V.; Jia, W.; Kadowaki, T.; Yajnik, C.S.; Yoon, K.H.; Hu, F.B. Diabetes in Asia: Epidemiology, risk factors, and pathophysiology. JAMA 2009, 301, 2129-2140. [CrossRef]

8. Bragg, F.; Holmes, M.V.; Iona, A.; Guo, Y.; Du, H.; Chen, Y.; Bian, Z.; Yang, L.; Herrington, W.; Bennett, D.; et al. Association Between Diabetes and Cause-Specific Mortality in Rural and Urban Areas of China. JAMA 2017, 317, 280-289. [CrossRef] [PubMed]

9. Ng, M.C.; Park, K.S.; Oh, B.; Tam, C.H.; Cho, Y.M.; Shin, H.D.; Cho, N.H. Implication of ge netic variants near TCF7L2, SLC30A8, HHEX, CDKAL1,CDKN2A/B, IGF2BP2, and FTO in type 2 diabetes and obesity in 6719 Asians. Diabetes 2008, 57, 2226-2233. [CrossRef]

10. Chang, Y.C.; Chang, T.J.; Jiang, Y.D.; Kuo, S.S.; Lee, K.C.; Chiu, K.C.; Chuang, L.M. Associa tion study of the genetic polymorphisms of the tran scription factor 7-like 2 (TCF7L2) gene and type 2 dia betes in the Chinese population. Diabetes 2007, 56, 2631-2637. [CrossRef]

11. Ma, R.C.; Chan, J.C. Type 2 diabetes in East Asians: Similarities and differences with populations in Europe and the United States. Ann. N. Y. Acad Sci. 2013, 1281, 64-91. [CrossRef]

12. Cho, Y.M. Characteristics of the pathophysiology of type 2 diabetes in Asians. Ann. Laparosc. Endosc. Surg. 2017, 2, 14. [CrossRef]

13. Jensen, E.T.; Dabelea, D. Type 2 Diabetes in Youth: New Lessons from the SEARCH Study. Curr. Diabetes Rep. 2018, 18, 36. [CrossRef]

14. Lee, K.W.; Ching, S.M.; Ramachandran, V.; Yee, A.; Hoo, F.K.; Chia, Y.C.; Veettil, S.K. Prevalence and risk factors of gestational diabetes mellitus in Asia: A systematic review and meta-analysis. BMC Pregnancy Childbirth 2018, 18, 1-20. [CrossRef]

15. Sone, $\mathrm{H}$. Clinical and pathophysiological features of Japanese patients with type 2 diabetes mellitus and their risk factors for diabetic complication. Nihon Rinsho. Jpn. J. Clin. Med. 2015, 73, 1979-1987.

16. Chan, J.C.Y.; Chee, M.L.; Tan, N.Y.Q.; Cheng, C.-Y.; Wong, T.Y.; Sabanayagam, C. Differential effect of body mass index on the incidence of diabetes and diabetic retinopathy in two Asian populations. Nutr. Diabetes 2018, 8, 16. [CrossRef]

17. Unger, R.H.; Clark, G.O.; Scherer, P.E.; Orci, L. Lipid homeostasis, lipotoxicity and the metabolic syndrome. Biochim. Biophys. Acta (BBA)-Mol. Cell Biol. Lipids 2010, 1801, 209-214. [CrossRef] [PubMed]

18. Yabe, D.; Seino, Y.; Fukushima, M.; Seino, S. $\beta$ Cell Dysfunction Versus Insulin Resistance in the Pathogenesis of Type 2 Diabetes in East Asians. Curr. Diabetes Rep. 2015, 15, 1-9. [CrossRef]

19. Cheng, H.; Weiping, J. Diabetes in China: Epidemiology and Genetic Risk Factors and Their Clinical Utility in Personalized Medication. Diabetes 2018, 67, 3.

20. International Diabetes Federation. IDF Diabetes Atlas, 8th ed.; International Diabetes Federation: Brussels, Belgium, 2017.

21. Chawla, A.; Chawla, R.; Jaggi, S. Microvasular and macrovascular complications in diabetes mellitus: Distinct or continuum? Indian J. Endocrinol. Metab. 2016, 20, 546-551. [CrossRef] [PubMed] 
22. Coope, A.; Torsoni, A.S.; Velloso, L.A. Mechanisms in Endocrinology: Metabolic and inflammatory pathways on the pathogenesis of type 2 diabetes. Eur. J. Endocrinol. 2016, 174, R175-R187. [CrossRef]

23. Sanada, F.; Taniyama, Y.; Muratsu, J.; Otsu, R.; Shimizu, H.; Rakugi, H.; Morishita, R. Source of Chronic Inflammation in Aging. Front. Cardiovasc. Med. 2018, 5, 12. [CrossRef]

24. Eguchi, K.; Nagai, R. Islet inflammation in type 2 diabetes and physiology. J. Clin. Investig. 2017, 127, 14-23. [CrossRef]

25. Lascar, N.; Afzal, I.; Nevill, A.M.; Shabir, K.; Ioannis Kyrou Brown, J.E.; Bellary, S. Increased Circulating Levels of Inflammatory Markers in A Cohort of Adults with Youth-Onset Type 2 Diabetes Mellitus. J. Diabetes Metab. 2020, 11, 853.

26. Chaudhury, A.; Duvoor, C.; Reddy Dendi, V.S.; Kraleti, S.; Chada, A.; Ravilla, R.; Mirza, W. Clinical review of antidiabetic drugs: Implications for type 2 diabetes mellitus management. Front. Endocrinol. 2017, 8, 6. [CrossRef]

27. Chan, J.C.; Bunnag, P.; Chan, S.P.; Tan, I.T.; Tsai, S.-T.; Gao, L.; Landgraf, W. Glycaemic responses in Asian and non-Asian people with type 2 diabetes initiating insulin glargine 100 units $/ \mathrm{mL}$ : A patient-level pooled analysis of 16 randomised controlled trials. Diabetes Res. Clin. Pract. 2017, 135, 199-205. [CrossRef] [PubMed]

28. Ni, L.; Yuan, C.; Chen, G.; Zhang, C.; Wu, X. SGLT2i: Beyond the glucose-lowering effect. Cardiovasc. Diabetol. 2020, 19, 1-10. [CrossRef] [PubMed]

29. Yang, L.; Zhang, L.; He, H.; Zhang, M.; An, Z. Efficacy and Safety of Sodium-Glucose Cotransporter 2 Inhibitors in East Asians with Type 2 Diabetes: A Systematic Review and Meta-Analysis. Diabetes Ther. 2019, 10, 1921-1934. [CrossRef]

30. Frampton, J.E. Empagliflozin: A Review in Type 2 Diabetes. Drugs 2018, 78, 1037-1048. [CrossRef]

31. Zelniker, T.A.; Wiviott, S.D.; Raz, I.; Im, K.; Goodrich, E.L.; Bonaca, M.P. SGLT2 inhibitors for primary and secondary prevention of cardiovascular and renal outcomes in type 2 diabetes: A systematic review and meta-analysis of cardiovascular outcome trials. Lancet 2019, 393, 31-39. [CrossRef]

32. Sjöström, C.D.; Johansson, P.; Ptaszynska, A.; List, J.; Johnsson, E. Dapagliflozin lowers blood pressure in hypertensive and non-hypertensive patients with type 2 diabetes. Diabetes Vasc. Dis. Res. 2015, 12, 352-358. [CrossRef]

33. Pancholia, A. Sodium-glucose cotransporter-2 inhibition for the reduction of cardiovascular events in high-risk patients with diabetes mellitus. Indian Heart J. 2018, 70, 915-921. [CrossRef]

34. Merovci, A.; Mari, A.; Solis, C.; Xiong, J.; Daniele, G.; Chavez-Velazquez, A.; DeFronzo, R.A. Dapagliflozin lowers plasma glucose concentration and improves $\beta$-cell function. J. Clin. Endocrinol. Metabolism. 2015, 100, 1927-1932. [CrossRef]

35. Jurczak, M.J.; Saini, S.; Ioja, S.; Costa, D.K.; Udeh, N.; Zhao, X.; Whaley, J.M.; Kibbey, R.G. SGLT2 knockout prevents hyperglycemia and is associated with reduced pancreatic $\beta$-cell death in genetically obese mice. Islets 2018, 10, 181-189. [CrossRef]

36. Bonner, C.; Kerr-Conte, J.J.; Gmyr, V.V.; Queniat, G.G.; Moerman, E.E.; Thévenet, J.J.; Beaucamps, C.C.; Delalleau, N.N.; Popescu, I.I.; Malaisse, W.J.; et al. Inhibition of the glucose transporter SGLT2 with dapagliflozin in pancreatic alpha cells triggers glucagon secretion. Nat. Med. 2015, 21, 512-517. [CrossRef] [PubMed]

37. E Inzucchi, S.; Zinman, B.; Wanner, C.; Ferrari, R.; Fitchett, D.; Hantel, S.; Espadero, R.-M.; Woerle, H.-J.; Broedl, U.C.; Johansen, O.E. SGLT-2 inhibitors and cardiovascular risk: Proposed pathways and review of ongoing outcome trials. Diabetes Vasc. Dis. Res. 2015, 12, 90-100. [CrossRef]

38. Sonesson, C.; Johansson, P.A.; Johnsson, E.; Gause-Nilsson, I. Cardiovascular effects of dapagliflozin in patients with type 2 diabetes and different risk categories: A meta-analysis. Cardiovasc. Diabetol. 2016, 15, 37. [CrossRef] [PubMed]

39. Inzucchi, S.E.; Bergenstal, R.M.; Buse, J.B.; Diamant, M.; Ferrannini, E.; Nauck, M.; Peters, A.L.; Tsapas, A.; Wender, R.; Matthews, D.R. Management of Hyperglycemia in Type 2 Diabetes, 2015: A Patient-Centered Approach: Update to a Position Statement of the American Diabetes Association and the European Association for the Study of Diabetes. Diabetes Care 2014, 38, 140-149. [CrossRef]

40. Araki, E.; Onishi, Y.; Asano, M.; Kim, H.; Ekholm, E.; Johnsson, E.; Yajima, T. Efficacy and safety of dapagliflozin in addition to insulin therapy in Japanese patients with type 2 diabetes: Results of the interim analysis of 16-week double-blind treatment period. J. Diabetes Investig. 2016, 7, 555-564. [CrossRef] [PubMed]

41. Handelsman, Y.; Bloomgarden, Z.T.; Grunberger, G.; Umpierrez, G.; Zimmerman, R.S.; Bailey, T.S.; Blonde, L.; Bray, G.A.; Cohen, A.J.; Dagogo-Jack, S.; et al. American Association Of Clinical Endocrinologists And American College Of Endocrinology -Clinical Practice Guidelines For Developing A Diabetes Mellitus Comprehensive Care Plan-2015. Endocr. Pract. 2015, 21, 1-87. [CrossRef]

42. Watts, N.B.; Bilezikian, J.P.; Usiskin, K.; Edwards, R.; Desai, M.; Law, G.; Meininger, G. Effects of Canagliflozin on Fracture Risk in Patients With Type 2 Diabetes Mellitus. J. Clin. Endocrinol. Metab. 2016, 101, 157-166. [CrossRef]

43. Shubrook, J.H.; Bokaie, B.B.; E Adkins, S. Empagliflozin in the treatment of type 2 diabetes: Evidence to date. Drug Des. Dev. Ther. 2015, 9, 5793-5803. [CrossRef]

44. Yoon, K.-H.; Nishimura, R.; Lee, J.; Crowe, S.; Salsali, A.; Hach, T.; Woerle, H.J. Efficacy and safety of empagliflozin in patients with type 2 diabetes from Asian countries: Pooled data from four phase III trials. Diabetes Obes. Metab. 2016, 18, 1045-1049. [CrossRef]

45. Yang, Y.; Chen, S.; Pan, H.; Zou, Y.; Wang, B.; Wang, G.; Zhu, H. Safety and efficiency of SGLT2 inhibitor combining with insulin in subjects with diabetes. Medicine 2017, 96, e6944. [CrossRef]

46. Molugulu, N.; Yee, L.S.; Ye, Y.T.; Khee, T.C.; Nie, L.Z.; Yee, N.J.; Yee, T.K.; Liang, T.C.; Kesharwani, P. Systematic review of metformin monotherapy and dual therapy with sodium glucose co-transporter 2 inhibitor (SGLT-2) in treatment of type 2 diabetes mellitus. Diabetes Res. Clin. Pract. 2017, 132, 157-168. [CrossRef] 
47. Han, E.; Kim, A.; Lee, S.J.; Kim, J.Y.; Kim, J.H.; Lee, W.J.; Lee, B.W. Characteristics of dapagliflozin responders: A longitudinal, prospective, nationwide dapagliflozin surveillance study in Korea. Diabetes Ther. 2018, 9, 1689-1701. [CrossRef]

48. Hong, A.R.; Koo, B.K.; Kim, S.W.; Yi, K.H.; Moon, M.K. Efficacy and safety of sodiumglucose cotransporter-2 inhibitors in Korean patients with type 2 diabetes mellitus in real-world clinical practice. Diabetes Metab. J. 2019, 43, 590-606. [CrossRef] [PubMed]

49. Huang, C.H.; Huang, Y.Y.; Hsu, B.R. A short-term follow-up of glycemic and body weight changes in diabetic patients who replaced dipeptidyl peptidase-4 inhibitors with the sodium-glucose cotransporter 2. Ann. Saudi Med. 2018, 38, 420-426. [CrossRef] [PubMed]

50. Huang, H.; Bell, K.F.; Gani, R.; Tugwell, C.W.; Eudicone, J.M.; Krukas-Hampel, M.R. A retrospective real-world study of dapagliflozin versus other oral antidiabetic drugs added to metformin in patients with type 2 diabetes. Am. J. Manag. Care. 2018, 24, S132-S137. [PubMed]

51. Seino, Y.; Yabe, D.; Sasaki, T.; Fukatsu, A.; Imazeki, H.; Ochiai, H.; Sakai, S. Sodium-glucose cotransporter-2 inhibitor luseogliflozin added to glucagon-like peptide 1 receptor agonist liraglutide improves glycemic control with bodyweight and fat mass reductions in Japanese patients with type 2 diabetes: A 52-week, open-label, single-arm study. J. Diabetes Investig. 2018, 9, 332-340.

52. Tobe, K.; Suganami, H.; Kaku, K. Sodium-glucose cotransporter 2 inhibitor, tofogliflozin, shows better improvements of blood glucose and insulin secretion in patients with high insulin levels at baseline. J. Diabetes Investig. 2017, 9, 862-869. [CrossRef] [PubMed]

53. Yabe, D.; Yasui, A.; Ji, L.; Lee, M.-K.; Ma, R.C.W.; Chang, T.-J.; Okamura, T.; Zeller, C.; Kaspers, S.; Lee, J.; et al. Safety and tolerability of empagliflozin in East Asian patients with type 2 diabetes: Pooled analysis of phase I-III clinical trials. J. Diabetes Investig. 2018, 10, 418-428. [CrossRef] [PubMed]

54. Yang, W.; Ma, J.; Li, Y.; Li, Y.; Zhou, Z.; Kim, J.H.; Ptaszynska, A. Dapagliflozin as add-on therapy in Asian patients with type 2 diabetes inadequately controlled on insulin with or without oral antihyperglycemic drugs: A randomized controlled trial. $J$. Diabetes 2018, 10, 589-599. [CrossRef] [PubMed]

55. Kawamori, R.; Haneda, M.; Suzaki, K.; Cheng, G.; Shiki, K.; Miyamoto, Y.; Solimando, F.; Lee, C.; Lee, J.; George, J. Empagliflozin as add-on to linagliptin in a fixed-dose combination in Japanese patients with type 2 diabetes: Glycaemic efficacy and safety profile in a 52-week, randomized, placebo-controlled trial. Diabetes Obes. Metab. 2018, 20, 2200-2209. [CrossRef]

56. Kutoh, E.; Wada, A.; Murayama, T.; Hayashi, J. Two Glucose-Lowering Mechanisms of Canagliflozin Depending on Body Weight Changes in Drug-Naïve Subjects with Type 2 Diabetes. Drugs R D 2018, 18, 309-315. [CrossRef]

57. Osonoi, T.; Gouda, M.; Kubo, M.; Arakawa, K.; Hashimoto, T.; Abe, M. Effect of Canagliflozin on Urinary Albumin Excretion in Japanese Patients with Type 2 Diabetes Mellitus and Microalbuminuria: A Pilot Study. Diabetes Technol. Ther. 2018, 20, 681-688. [CrossRef]

58. Furukawa, S.; Miyake, T.; Senba, H.; Sakai, T.; Furukawa, E.; Yamamoto, S.; Niiya, T.; Matsuura, B.; Hiasa, Y. The effectiveness of dapagliflozin for sleep-disordered breathing among Japanese patients with obesity and type 2 diabetes mellitus. Endocr. J. 2018, 65, 953-961. [CrossRef]

59. Han, K.A.; Chon, S.; Chung, C.H.; Lim, S.; Lee, K.W.; Baik, S.; Lee, M.K. Efficacy and safety of ipragliflozin as an add-on therapy to sitagliptin and metformin in Korean patients with inadequately controlled type 2 diabetes mellitus: A randomized controlled trial. Diabetes Obes. Metab. 2018, 20, 2408-2415. [CrossRef] [PubMed]

60. Lu, C.H.; Min, K.W.; Chuang, L.M.; Kokubo, S.; Yoshida, S.; Cha, B.S. Efficacy, safety, and tolerability of ipragliflozin in Asian patients with type 2 diabetes mellitus and inadequate glycemic control with metformin: Results of a phase 3 randomized, placebo-controlled, double-blind, multicenter trial. J. Diabetes Investig. 2016, 7, 366-373. [CrossRef]

61. Zinman, B.; Wanner, C.; Lachin, J.M.; Fitchett, D.; Bluhmki, E.; Hantel, S.; Inzucchi, S.E. Empagliflozin, cardiovascular outcomes, and mortality in type 2 diabetes. N. Engl. J. Med. 2015, 373, 2117-2128. [CrossRef]

62. Baglioni, P.; Wiviott, S.D.; Raz, I.; Sabatine, M.S.; Akinci, B. Dapagliflozin and Cardiovascular Outcomes in Type 2 Diabetes. N. Engl. J. Med. 2019, 380, 1880-1881. [CrossRef]

63. Neal, B.; Perkovic, V.; Matthews, D.R. Canagliflozin and cardiovascular and renal events in type 2 diabetes. N. Engl. J. Med. 2017, 377, 2099. [CrossRef] [PubMed]

64. Kashiwagi, A.; Araki, S.; Maegawa, H. Sodium-glucose cotransporter 2 inhibitors represent a paradigm shift in the prevention of heart failure in type 2 diabetes patients. J. Diabetes Investig. 2021, 12, 6-20. [CrossRef] [PubMed]

65. Shah, K.S.; Fang, J.C. Sodium-Glucose Cotransporter 2 Inhibitors in Heart Failure. Annu. Rev. Pharmacol. Toxicol. $2021,62$. [CrossRef] [PubMed]

66. Dekkers, C.C.J.; Sjöström, C.D.; Greasley, P.J.; Cain, V.; Boulton, D.W.; Heerspink, H.J.L. Effects of the sodium-glucose cotransporter-2 inhibitor dapagliflozin on estimated plasma volume in patients with type 2 diabetes. Diabetes Obes. Metab. 2019, 21, 2667-2673. [CrossRef] [PubMed]

67. Nojima, T.; Matsubayashi, Y.; Yoshida, A.; Suganami, H.; Abe, T.; Ishizawa, M.; Sone, H. Influence of an SGLT2 inhibitor, tofogliflozin, on the resting heart rate in relation to adipose tissue insulin resistance. Diabet. Med. 2020, 37, 1316-1325. [CrossRef]

68. Núñez, J.; Palau, P.; Domínguez, E.; Mollar, A.; Núñez, E.; Ramón, J.M.; Miñana, G.; Santas, E.; Fácila, L.; Górriz, J.L.; et al. Early effects of empagliflozin on exercise tolerance in patients with heart failure: A pilot study. Clin. Cardiol. 2018, 41, 476-480. [CrossRef]

69. Carbone, S.; Canada, J.M.; Billingsley, H.E.; Kadariya, D.; Dixon, D.L.; Trankle, C.R.; Abbate, A. Effects of empagliflozin on cardiorespiratory fitness and significant interaction of loop diuretics. Diabetes Obes. Metab. 2018, 20, 2014-2018. [CrossRef] 
70. Packer, M. SGLT2 Inhibitors Produce Cardiorenal Benefits by Promoting Adaptive Cellular Reprogramming to Induce a State of Fasting Mimicry: A Paradigm Shift in Understanding Their Mechanism of Action. Diabetes Care 2020, 43, 508-511. [CrossRef]

71. Scheen, A.J. Effect of SGLT2 Inhibitors on the Sympathetic Nervous System and Blood Pressure. Curr. Cardiol. Rep. 2019, 21, 70. [CrossRef]

72. Kario, K.; Ferdinand, K.C.; O'Keefe, J.H. Control of 24-hour blood pressure with SGLT2 inhibitors to prevent cardiovascular disease. Prog. Cardiovasc. Dis. 2020, 63, 249-262. [CrossRef] [PubMed]

73. Li, H.; Shin, S.E.; Seo, M.S. The anti-diabetic drug dapagliflozin induces vasodilation via activation of PKG and Kv channels. Life Sci. 2018, 197, 46-55. [CrossRef]

74. Packer, M.; Anker, S.D.; Butler, J.; Filippatos, G.; Zannad, F. Effects of sodiumglucose cotransporter 2 inhibitors for the treatment of patients with heart failure: Proposal of a novel mechanism of action. JAMA Cardiol. 2017, 2, 1025-1029. [CrossRef]

75. Mabillard, H.; Sayer, J.A. SGLT2 inhibitors-a potential treatment for Alport syndrome. Clin. Sci. 2020, 134, 379-388. [CrossRef]

76. Kaplan, A.; Abidi, E.; El-Yazbi, A.; Eid, A.; Booz, G.W.; Zouein, F.A. Direct cardiovascular impact of SGLT2 inhibitors: Mechanisms and effects. Hear. Fail. Rev. 2018, 23, 419-437. [CrossRef]

77. Mathieu, C.; Van Den Mooter, L.; Eeckhout, B. Empagliflozin in type 1 diabetes. Diabetes Metab Syndr. Obes. 2019, $12,1555-1561$. [CrossRef]

78. Vallon, V.; Thomson, S.C. Targeting renal glucose reabsorption to treat hyperglycaemia: The pleiotropic effects of SGLT2 inhibition. Diabetologia 2017, 60, 215-225. [CrossRef] [PubMed]

79. Lee, T.M.; Chang, N.C.; Lin, S.Z. Dapagliflozin, a selective SGLT2 Inhibitor, attenuated cardiac fibrosis by regulating the macrophage polarization via STAT3 signaling in infarcted rat hearts. Free Radic. Biol. Med. 2017, 104, 298-310. [CrossRef] [PubMed]

80. Lim, V.G.; Bell, R.M.; Arjun, S.; Kolatsi-Joannou, M.; Long, D.A.; Yellon, D.M. SGLT2 inhibitor, canagliflozin, attenuates myocardial infarction in the diabetic and nondiabetic heart. J. Am. Coll. Cardiol. Basic. Trans. Science. 2019, 4, 15-26. [CrossRef]

81. Sato, T.; Aizawa, Y.; Yuasa, S.; Kishi, S.; Fuse, K.; Fujita, S.; Ikeda, Y.; Kitazawa, H.; Takahashi, M.; Sato, M.; et al. The effect of dapagliflozin treatment on epicardial adipose tissue volume. Cardiovasc. Diabetol. 2018, 17, 1-9. [CrossRef] [PubMed]

82. Lin, B.; Koibuchi, N.; Hasegawa, Y.; Sueta, D.; Toyama, K.; Uekawa, K.; Ma, M.; Nakagawa, T.; Kusaka, H.; Kim-Mitsuyama, S. Glycemic control with empagliflozin, a novel selective SGLT2 inhibitor, ameliorates cardiovascular injury and cognitive dysfunction in obese and type 2 diabetic mice. Cardiovasc. Diabetol. 2014, 13, 1-15. [CrossRef] [PubMed]

83. Verma, S.; Rawat, S.; Ho, K.L.; Wagg, C.S.; Zhang, L.; Teoh, H.; Lopaschuk, G.D. Empagliflozin increases cardiac energy production in diabetes: Novel translational insights into the heart failure benefits of SGLT2 inhibitors. J. Am. Coll. Cardiol. Basic Trans. Sci. 2018, 3, 575-587.

84. Cavender, M.A.; Norhammar, A.; Birkeland, K.I.; Jorgensen, M.E.; Wilding, J.P.; Khunti, K.; Fu, A.Z.; Bodegard, J.; Blak, B.T.; Wittbrodt, E.; et al. SGLT-2 inhibitors and cardiovascular risk: An analysis of CVD-REAL. J. Am. Coll. Cardiol. 2018, 71, $2497-2506$. [CrossRef]

85. Norhammar, A.; Bodegard, J.; Nystrom, T.; Thuresson, M.; Nathanson, D.; Eriksson, J.W. Dapagliflozin and cardiovascular mortality and disease outcomes in a population with type 2 diabetes similar to that of the DECLARE-TIMI 58 trial: A nationwide observational study. Diabetes Obes. Metabolism. 2019, 21, 1136-1145. [CrossRef]

86. Wiviott, S.D.; Raz, I.; Bonaca, M.P.; Mosenzon, O.; Kato, E.T.; Cahn, A.; Silverman, M.G.; Zelniker, T.A.; Kuder, J.F.; Murphy, S.A.; et al. Dapagliflozin and cardiovascular outcomes in type 2 diabetes. N. Engl. J. Med. 2019, 380, 347-357. [CrossRef]

87. Cai, X.; Yang, W.; Gao, X.; Chen, Y.; Zhou, L.; Zhang, S.; Han, X.; Wenjia, Y. The Association Between the Dosage of SGLT2 Inhibitor and Weight Reduction in Type 2 Diabetes Patients: A Meta-Analysis. Obesity 2017, 26, 70-80. [CrossRef]

88. Woo, V.C. Cardiovascular Effects of Sodium-Glucose Cotransporter-2 Inhibitors in Adults with Type 2 Diabetes. Can. J. Diabetes 2019, 44, 61-67. [CrossRef]

89. Kim, E.J.; Choi, M.J.; Lee, J.H.; Oh, J.E.; Seo, J.W.; Lee, Y.K.; Koo, J.R. Extracellular fluid/intracellular fluid volume ratio as a novel risk indicator for all-cause mortality and cardiovascular disease in hemodialysis patients. PLoS ONE 2017, 12, e0170272. [CrossRef]

90. Rosenstein, R.; Hough, A. Empagliflozin, cardiovascular outcomes, and mortality in type 2 diabetes. N. Engl. J. Med. 2016, 374, 1093-1094. [PubMed] 